Короткевич В.

н.с., Національний інститут освіти (Республіка Білорусь)

Karatkevich $\boldsymbol{V}$.

Researcher, Institution National Institute of Education (Republic of Belarus)

\author{
СПЕЦЫФІКА ПСІХАЛАГІЧНАГА АСПЕКТУ \\ ФАРМІРАВАННЯ Ў НАВУЧЭНЦА ̈̆ АСОБАСНЫХ \\ І МЕТАПРАДМЕТНЫХ КАМПЕТЭНЦЫЙ \\ У ПРАЦЭСЕ НАВУЧАННЯ ЛІТАРАТУРЫ
}

\title{
THE SPECIFICS OF THE PSYCHOLOGICAL ASPECT OF THE FORMATION OF STUDENTS' PERSONAL AND METADISCIPLINARY COMPETENCIES IN TEACHING LITERATURE
}

Суспільство зачікавлене в особистостях, здатних проявляти гнучкість мислення, вміння орієнтуватися в світі, щуо змінюється, мобільних і креативних. Освіта сьогодні має також реагувати на иі виклики часу: забезпечувати потреби в навчанні через все життя. Тому однією з ключових проблем сучасної системи освіти є формування метапредметних і особистісних компетенцій, спрямованих на адаптачію учня в надзвичайно мінливому світі. У ичій статті визначаються такі поняття, як виховання в психологічному аспекті і психологічний аспект виховання, представляються принщипи відбору навчального матеріалу для формування метапредметних і особистісних компетениій.

Ключові слова: особистісна компетенція, метапредметна компетенція, психологічний аспект, педагогіка, навчання, виховання, література.

The society is interested in individuals capable of showing flexibility of thinking, ability to navigate in a changing world, mobile and creative. Provisioning today must also respond to these challenges of the time: to provide lifelong learning needs. The refore, one of the key problems of the modern education system is the formation of metadisciplinary and personal competencies aimed at adapting the student in a rapidly changing world. At the sametime, it is important to understand the psychological aspect of the formation of these competencies. The implementation of education through training, the creation of conditions for self-realization are the most important components of modern education. In this article deals with defines such concepts as upbringing in the psychological aspect and the psychological aspect of upbringing, presents the principles for the selection of educational material for the formation of metadisciplinary and personal competences.

Key words: personal competence, metasubject competence, psychological aspect, pedagogy, training, education, literature. 
Пастаноўка праблемы. Сучаснае грамадства змяняецца дастаткова хутка. Адной з умоў паспяховай рэалізацыі асобы з'яўляецца здольнасць да самаразвіцця. самаадукацыі, уменне i жаданне самаўдасканальвацца. Грамадства зацікаўлена ў асобах, якія могуць праяўляць гнуткасць, мабільнасць, крэатыўнасць. Таму перад сістэмай адукацыі стаіць важная задача: не простадаць пэўную колькасць ведаўчалавеку, а забяспечыць яго агульнакультурнае, асобаснае развіццё, навучыць вучыцца. Менавіта на гэта скіраваны метапрадметныя i асобасныя кампетэнцыі. Праз метапрадметнасць ажыццяўляецца ўключэнне дзіця ў розныя тыпы дзейнасці, што стварае ўмовы для яго развіцця.

Аналіз апошніх даследаванняу. Значнымі публікацыямі ў межах нашага даследавання 3'яўляюцца працы А.В. Хутарскога [Khutorskoy 2004; Khutorskoy 2012A; Khutorskoy 2012B; Khutorskoy 2012C], у якіх разглядаюцца асноўныя падыходы да фарміравання метапрадметных кампетэнцый і прынцыпова важных змен у падыходах да сучаснай сістэмы адукацыі.

Д.Г. Артамонаў у сваім артыкуле "Псіхалагічныя аспекты аналізу твораў мастацтва" [Artamonov 2012] разглядае асноўныя напрамкі псіхалагічных даследаванняў твораў мастацтва, дае метадычны агляд розных падыходаў да класіфікацыі ўзаемадзеяння твораў псіхалогіі і эстэтыкі.

Як правіла, даследчыкі не так часта звяртаюцца да псіхалагічных аспектау фарміравання кампетэнцый. Наша даследаванне таксама не мае на мэце даць вычарпальны аналіз акрэсленых праблем.

Мэтай нашага даследавання з'яўляецца выяўленне спецыфічных рыс псіхалагічнага аспекту фарміравання ў навучэнцаў асобасных i метапрадметных кампетэнцый у працэсе навучання літаратуры. Пры гэтым важна разумець, што у гэтым працэсе немалаважную ролю адыгрывае выхаванне. Для дасягнення пастаўленай мэты неабходна вырашэнне наступных задач: вызначэнне сутнасці псіхалагічнага аспекту выхавання і выхавання ў псіхалагічным аспекце; вызначэнне прынцыпаў адбору зместу навучання, накіраванага на фарміраванне такога роду кампетэнцый.

Адным 3 прыярытэтных напрамкаў развіцця сістэмы адукацыі з'яўляецца падрыхтоўка высокаадукаваных людзей, кваліфікаваных спецыялістаў, здатных да творчай дзейнасці, прафесійнага развіцця, засваення і суправаджэння навукаёмістых і інфармацыйных тэхналогій. Пры гэтым не павінен адыходзіць на другі план працэс выхавання. У сувязі са зменай сацыяльных выклікаў адбываецца пераасэнсаванне ролі 
настаўніка ў працэсе мадэрнізацы адукацыйнай прасторы. Крытычнакрэатыўная парадыгма асветы патрабуе высокай прафесійнай кампетэнтнасці настаўніка, яго гатоўнасці да сутворчасці, супрацоўніцтва са сваімі вучнямі, да здзяйснення асабіста арыентаванага навучання.

Разам 3 тым, стратэгічнай задачай сучаснай адукацыі 3'яўляецца фарміраванне кампетэнцый, неабходных для адаптацы ў грамадстве, розных сацыяльных асяродках. У Канцэптуальных падыходах да развіцця сістэмы адукацыі да 2020 года і на перспектыву да 2030 года дакуменце, які рэалізуецца ў Рэспубліцы Беларусь, - канстатуецца выхаваўчы патэнцыял сістэмы адукацыі, накіраваны на актыўнае садзейнічанне асобаснаму станаўленню грамадзяніна, прафесіяналапрацаўніка, адказнага сем'яніна. Рэалізацыя пастаўленых задач забяспечваецца праз змест вучэбных праграм вучэбных прадметаў i праграм выхавання. Канцэпцыя бесперапыннага выхавання дзяцей i вучнёўскай моладзі дэкларуе, што змест выхавання рэалізуецца шляхам выкарыстання патэнцыялу вучэбных прадметаў, факультатыўных заняткаў, розных форм дадатковай адукацыі дзяцей і моладзі.

Рэалізацыя пастаўленых задач абцяжарваецца недастатковай распрацаванасцю метадычнага забеспячэння выхаваўчага працэсу на вучэбных занятках і пазакласнай рабоце па прадмеце.

Літаратура як вучэбны прадмет мае амаль невычарпальны выхаваўчы патэнцыял. Праз мастацкі тэкст чалавек можа пазнаёміцца 3 вялікай парадыгмай эмоцый, перажыванняў, псіхалагічных зрухаў і інш.

Асноўнымі прынцыпамі адбору зместу навучання, накіраванага на фарміраванне асобасных і метапрадметных кампетэнцый (псіхалагічны аспект), з'яўляюцца:

Прынщыл асобаснай арыентащыі. Вядучым суб'ектам навучальнага працэсу прызнаецца навучэнец; адукацыя найперш арыентуецца на фарміраванне асобасных і метапрадметных кампетэнцый.

Прыниылп фарміравання ўніверсальных спосабаў дзейнасиі $i$ ix паслядойнасці. Сутнасць заключаецца ў тым, што навучэнец не толькі засвойвае канкрэтныя веды, набывае ўменні і навыкі, але і авалодвае ўніверсальнымі спосабамі дзейнасці, неабходнымі для дасягнення асобасных і метапрадметных вынікаў. Пад універсальнымі спосабамі дзейнасці разумеюцца, напрыклад, спосабы бібліяграфічнага пошуку, класіфікацыі і размежавання інфармацыі, стварэння канчатковых прадуктаў вучэбнай дзейнасці і інш. 
Прынщыл саџыялізаџыі адукаџыйнай дзейнасиі. Праяўляецца ў тым, што навучанне арганізуецца ў адзінстве інварыянтнага i варыятыўнага кампанентаў зместу літаратурнай адукацыі на розных узроўнях.

Да ключавых асобасных і метапрадметных кампетэнщый, якія будуць фарміравацца ў працэсе вывучэння мастацкіх твораў, трэба аднесці наступныя: сацыяльная (здольнасць дзейнічаць у соцыуме 3 улікам псіхалагічных пазіцый іншых людзей); камунікатыўная (здольнасць уступаць у камунікацыю 3 мэтай быць зразумелым); прадметная (здольнасць экстрапаляваць набыты вопыт на розныя галіны культуры); інфармацыйная (здольнасць авалодваць інфармацыйнымі тэхналогіямі і апрацоўваць розныя віды інфармацыі (у т. л. праз вербальныя і невербальныя зносіны)); аўтанамізацыйная (здольнасць да самаразвіцця, самавызначэння, самаадукацыі, канкурэнтназдольнасці); прадуктыўная (здольнасць ствараць канчатковыя прадукты сваёй дзейнасці, прымаць пэўныя рашэнні і несці за іх адказнасць); маральная (гатоўнасць дзейнічаць у адпаведнасці з традыцыйнымі маральнымі законамі).

Псіхалагічны аспект выхавання накіраваны на азнаямленне навучэнцаў 3 заканамернасцямі развіцця асобы і правіламі нарматыўных паводзін у адпаведнасці з маральнымі законамі, атрыманне інфармацыі пра характар, настрой чалавека вербальнымі і невербальнымі сродкамі і інш.

Выхаванне ў псіхалагічным аспекце разумеецца ў шырокім сэнсе як працэс сацыялізацыі асобы на працягу жыцця праз уласную актыўнасць i пад уплывам асяродку, у т. л. штучна створаным бацькамі і педагогамі. У вузкім сэнсе выхаванне ў псіхалагічным аспекце - набыццё асобай адобраных грамадствам сацыяльных каштоўнасцяў, маральных і прававых норм, якасцяу i ўзораў паводзін у працэсе адукацыі. Абодва гэтыя падыходы не выключаюць выхаванне як узаемадзеянне ўнутраных псіхічных працэсаў, звязаных з актыўным самаразвіццём, самарэалізацыяй i знешніх уплываў. У выніку такога ўзаемадзеяння фарміруецца індывідуальнасць i ідэнтычнасць як спалучэнне інтэлектуальных i сацыякультурных ведаў, перажыванняў, вопыту. Змест выхавання ў такім выпадку ўвасоблены ў межах маралі і права.

Псіхалогія і літаратура маюць цесную ўзаемасувязь. Літаратура заўсёды давала матэрыял для асэнсавання дзеянняу і ўчынкаў чалавека (3. Фрэйд, К. Юнг, К. Леангард і інш.), а псіхалогія давала магчымасць спасцігнуць глыбінную сутнасць мастацкага вобраза. 
Школьны аналіз мастацкага твора 3 пазіцый псіхалагічнага літаратуразнаўства (А. Патабня, Д. Аўсяніка-Кулікоўскі, В. Бялянін і інш.) дапамагае вырашыць некалькі праблем. Па-першае, няўменне дыферэнцыраваць “асяродак” уздзеяння на літаратуру як набор шматлікіх фактараў. Па-другое, няўвага, нават пагарда да эстэтычнай прыроды літаратуры, растварэнне спецыфічнага зместу мастацкага мыслення ў агульнакультурнай праблематыцы, звядзенне гісторыі літаратуры да гісторыі грамадскай думкі.

Псіхалагічны падыход дае штуршок да асэнсавання літаратуры як віду мастацтва і спосабу пазнання свету. Сёння, як ніколі, актуалізуецца псіхалагізацыя навучання беларускай літаратуры: улік узроставых псіхалагічных асаблівасцей вучняў, увядзенне пэўных катэгорый псіхалагічнай навукі ў школьны аналіз мастацкага твора, увага да псіхалогіі чытання і творчасці.

Псіхалагічнае даследаванне, якое праводзіць вучань на III ступені атрымання сярэдняй адукацыі (10-11 класы), мае для яго падвоеную матывацыю: пазнанне літаратуры на новым узроўні і пазнанне ўласнага ўнутранага свету. Веды па псіхалогіі, вопыт характарыстыкі асобы літаратурнага героя, які вучань набывае на ўроку-даследаванні, ён экстрапалюе на сябе. Такім чынам адбываецца пазнанне ўласнага ўнутранага свету і наваколля на новым узроўні.

Прадуктыўнымі для школьнага псіхалагічнага даследавання можа стаць, напрыклад, выяўленне архетыпных вобразаў - вобразаў, якія сфарміраваліся пад уплывам вопыту продкаў і паслядоўна паўтараюцца працяглы час у культуры. Правядзенне такога пошуку дасць магчымасць, напрыклад, не толькі асэнсаваць твор на новым узроўні, але і засвоіць каштоўныя нематэрыяльныя набыткі беларусаў. Напрыклад, пры аналізе творчасці Яна Баршчэўскага неабходна правесці гутарку пра рэалізацыю архетыпу маці ў апавяданні "Плачка", а праз корпус пэўных заданняў дапамагчы асэнсаваць гэты архетып праз іншыя вобразы іншых нацыянальных літаратур і іншых відаў мастацтва (жывапіс, скульптура і г. д.).

Не менш эфектыўнай з'яўляецца даследчая дзейнасць. Выкарыстанне элементаў пошукавых. праблемных, даследчых метадаў павышаюць прадуктыўнасць адукацыйнага працэсу. Развіццё даследчых уменняў навучэнцаў дапамагае павысіць матывацыю. цікавасць да навучання. Праз 
пошук ствараюцца ўмовы для самарэалізацыі асобы дзіцяці, бо відавочным з'яўляецца прадукт дзейнасці.

Bblсновы. Метапрадметны i асобасна арыентаваныя падыходы да мадэлявання вучэбнага прадмета прадугледжваюць такую арганізацыю адукацыі, калі навучэнец успрымае веды не як суму ведаў для запамінання, а як веды, якія ён асэнсоўвае i можа прымяніць на практыцы ў жыцці. Пры навучанні літаратуры важную ролю адыгрывае псіхалагічны аспект, які пашырае магчымасці зместу навучання пры фарміраванні асобасных і метапрадметных кампетэнцый. Для паспяховага ажыццяўлення выхавання праз адукацыю трэба прытрымлівацца пэўных прынцыпаў адбору зместу навучання.

\section{REFERENCES:}

1. Artamonov, D.G. (2012) Psikhologicheskie aspekty analiza proizvedeny iskusstva. Severo-Kavkazsky psikhologichesky vestnik. № 10/2, 38-42. (in Rus.).

2. Khutorskoy, A.V. (2012A) Metapredmetny podkhod v obuchenii : nauchnometodicheskoe posobie. Moskva : Èydos ; Izd-vo In-ta obrazovaniya cheloveka. 50 s. (in Rus.).

3. Khutorskoy, A.V. (2004) Praktikum po didaktike i metodikam obucheniya. SanktPeterburg : Piter. 288 s. (in Rus.).

4. Khutorskoy, A.V. (2012V) Sistemno-deyatel'nostny podkhod v obuchenii: nauchnometodicheskoe posobie. Moskva : Èydos ; Izd-vo In-ta obrazovaniya cheloveka. 63 s. (in Rus.). 5. Khutorskoy, A.V. (2012S) Chto takoe sovremenny urok. Internet-zhurnal "Èydos". (inRus.). URL: http://www.eidos.ru/journal/2012/0529-10.htm.

Левицький В. к.філол.н., головний спецііаліст державної служби Levytskyi $\boldsymbol{V}$. PhD in Philology, the general specialict of public service

\section{«ЛИСТ ПРО ЛАТИНИЦЮ» СЕРГІЯ ПИЛИПЕНКА ЯК ЛІТЕРАТУРНИЙ ЕКСПЕРИМЕНТ}

\section{‘THE LETTER ABOUT LATIN' BY SERHII PYLYPENKO AS THE LITERARY EXPERIMENT}

